\title{
Signatures factory: a dynamic alternative for teaching - learning layout concepts and waste disposal
}

\author{
Everton Luiz Vieira ${ }^{\text {** }}$ \\ aUnião de Ensino do Sudoeste do Paraná, Francisco Beltrão, PR, Brasil \\ *vieira@unisep.edu.br
}

\begin{abstract}
The use of games and simulation has now spread as a teaching support tool of engineering. This article aims to discuss this reality and this need, presenting as proposed a didactic game in a signature's factory. From this, it was suggested that the participants involved modify the simulated factory environment through the knowledge acquired during the factory design discipline and layout. Various topics related to Production Engineering were addressed, such as layout, Takt time (TT), standardization of processes, elimination of waste and activities that add / do not add value. As a result, it was possible to see, among many things, the significant improvement in the understanding and assimilation of theoretical concepts by the participants. With the practice of simulation one can demonstrate and experience possible cases and difficulties they face on a daily basis within the factory environment.
\end{abstract}

Keywords

Educational dynamics. Layout. Takt time. Kaizen. Production engineering.

How to cite this article: Vieira, E. L. (2017). Signatures factory: a dynamic alternative for teaching - learning layout concepts and waste disposal. Production, 27(spe), e20162217. http://dx.doi.org/10.1590/0103-6513.221716.

\section{Introduction}

The profile of undergraduate students has been changed, forcing a constant evolution in the teaching of Production Engineering, because of access to technologies available today. According to Carvalho et al. (2001), academic training of the engineer cannot be made only by formulas and concepts, one must be prepared to make decisions, seek information and know how to apply it, having a systemic view. According to Moscinski (2007), this is the great challenge of the role that the professor should play in the process of professional training.

Due to these factors, the traditional model in which the student attends class passively gives way to active learning. According to Auster \& Wylie (2006) active learning is characterized by the strong involvement of students in developing their own knowledge, who usually participate in practice drills and projects for real-world problem solving.

In Production Engineering, the transition for the active learning model has happened frequently in performing the creative dynamics of teaching. According to Santos et al. (2013), the use of these new approaches has been diffused as an effective alternative in assimilation of technical concepts. These dynamics often mimic the behavior of production systems and provide students the opportunity to experience situations that are usually described (but not tried) in lectures.

In this context, the aim of this paper is to present a didactic game as a support tool to the teaching of production engineering and the concepts presented in the course of Factory Design and Layout, through the simulation of a production process of a signature's factory, from which students can address various concepts relating to production systems, Takt Time (TT), Kaizen, process improvement and teamwork.

The article initially presents a brief literature review that identifies some of the most recently used teaching methodologies and highlights the application of didactic games and playful activities in engineering teaching. The article then describes in detail the methodology for developing the dynamics of the "Signatures Factory". 
In the last sections, the results of activity and a satisfaction survey that was applied to the participants are discussed, and the final considerations of work are presented.

\section{Teaching methodologies}

\subsection{Concept of learning}

According to Nunes \& Silveira (2008), so far, science has not been able to respond how the human brain changes with learning. It is suggested that there should be some modification in the nervous system, the nature of which has not yet been fully elucidated. Moreira et al. (1997), understand that learning is the process in which new information relates non-arbitrarily and substantive to the learner's cognitive structure, that is, learning is related to the ability to acquire and store ideas, giving them psychological significance.

\subsection{Learning styles}

According to Silva \& Silva (2006) learning styles are individual ways of perceiving and systematizing the experiences to which all individuals are exposed from birth, that is, the way in which the human being learns about things.

Felder \& Henriques (1995) consider that learning styles are the means that individuals use to acquire, retain and recover information; these learning must be taken into consideration by the teacher who wishes to maximize the learning of his class.

It is worth emphasizing that the teacher must use strategies to reach all learning styles, seeking to encourage the development of the class to maximize learning. Silva \& Silva (2006), understand that knowing how students learn helps to develop strategies that best fit the learning process of the same.

\subsection{Dynamics for the teaching-learning process}

Teaching methods have evolved over the years toward learning through direct involvement of students with the content taught and reality (Zepke \& Leach, 2010). In pursuit of this evolution, there comes the concept of active learning, defined in a simplified manner by Bonwell \& Eison (1991) as an approach that "involves students in doing things and thinking about what they are doing." Active learning is characterized by great involvement of students in the learning process (Heriot et al., 2008; Prince, 2004), improving their ability to convert theoretical concepts into practical knowledge.

Active learning is a broad term and can be manifested in various ways. According to Snider \& Balakrishnan (2013), experiential learning is a more intense form of active learning, since students have the opportunity to learn through direct experience with the object of study. Figure 1 shows the view of the authors for the different modes of active learning.

According to Bordenave \& Pereira (1985), progressive pedagogical approaches to teaching and learning have been constructed and involve training professionals as social subjects with ethical, political and technical skills and endowed with knowledge, reasoning, criticism, responsibility and sensitivity to issues of life and society, enabling them to intervene in contexts of uncertainties and complexities.

Currently, experiential education has been accomplished in the classroom through interactive learning dynamics. The application of teaching-learning dynamics within Production Engineering has been reported frequently in simulations and games involving concepts of production management. Snider \& Eliasson (2009), in turn, used $\mathrm{LEGO}^{\circledR}$ mounting parts to explain the differences between manufacturing and remanufacturing in programming environments with the MRP 1 (Material Requirements Planning) and MRP 11 (Manufacturing Resources Planning) systems.

Gokhale (1995) observed that students who participated in active teaching experiments performed better on critical analysis tests than students who studied individually. In international publications, it is also possible to identify dynamics that use different types of materials, such as data sets (Lambrecht et al., 2012), paper airplanes (Billington, 2004) or PVC connections (Santos et al., 2012) . In general, these dynamics require student participation in simulations that reproduce, by analogy, productive production environments and processes. This type of simulation is called Smeds (2003), a social simulation which differs from the computational simulation because it is characterized by human interactions among the participants. 


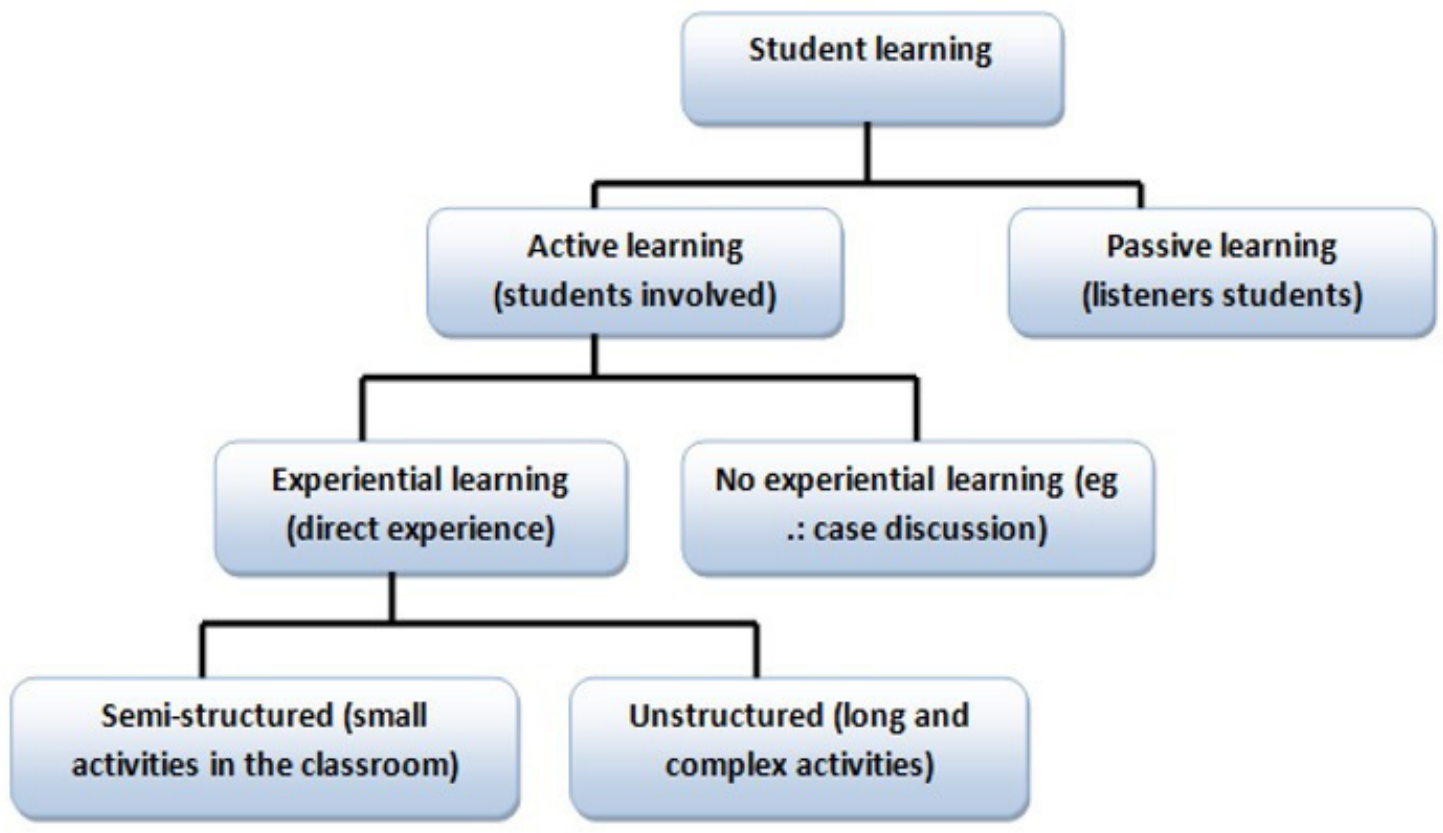

Figure 1. Active learning forms. Source: Adapted from Snider \& Balakrishnan (2013).

\subsection{Games and simulations in the Production Engineering area}

There are currently many countries that have used the application of business games as a complementary form of teaching, in order to realize the interaction between theory and practice, and the possibility of interaction of students with similar situations they will face in their professional future.

According to Mury (2002), company games are a kind of dynamic in which a decision-making exercise is performed in sequence, seeking systematic training of a team or group of teams working on the model of business operation in which participants take positions set as if they are within a company. Its main use today is principally in business training; however, one of the difficulties is to make the model as close to reality as possible.

According to Miyashita et al. (2003), in Brazil, the use of company games is still not appreciated, because for some people, business games still have a purely playful and time-consuming connotation. For Dillenbourg (1999), the validity of such games is still a paradigm in the process of change; the experiences of educators of several world-wide institutions have been positive and promote a transformation in the way of facing the complementarity of games when allied with traditional methods of teaching.

For the paradigm shift to occur, it takes the development of games for specific purposes that allow its implementation in various areas of Production Engineering. In addition, there should also be the motivation and awareness among educators of the need to add value and efficiency to their courses, as it is the experience of others, as well as studies, qualitative and quantitative, conducted on company games, which makes them more productive and effective in the teaching-learning process.

\section{Production concepts}

\subsection{Layout}

According to Nigel et al. (1999), the layout of productive operation is concerned with the physical location of processing resources (plant, machinery, operators). The layout is one of the most obvious characteristics of a production process, as it determines its own shape and appearance. The layout also determines how the resources processed (customer, product, materials and information) flow through the process.

The layout or physical arrangement is the rational organization of all resources and technologies needed to achieve the operational level of industry goals, materializing in the way these resources will be arranged in three-dimensional space. Rational organization means the pursuit of harmonization and integration of 
equipment, manual labor (direct and indirect), materials, areas of handling, storage and other resources and technologies (Olivério, 1985).

\subsubsection{Types of layouts}

There are four traditional types of layouts: functional layout or process layout by product or in line, positional layout and cell layout. The types of layouts found most often in companies are presented and characterized briefly below.

\subsubsection{Positional layout}

According to Krajewski \& Ritzman (1999), this layout is characterized by a spatial arrangement where the material to be processed (piece, part or item) remains static while the operators and equipment (processing resources) move in its direction. For Silva \& Rentes (2012), this is a very particular type of layout and is normally used in the manufacture of large products or products that will remain fixed at the place of manufacture. E.g. buildings, bridges, ships, heavy machinery, surgery, etc.

\subsubsection{Functional layout}

In this type of layout, devices are grouped according to similarity of operations in the production process regardless of the processed product. The grouping of similar machines is characteristic of this type of arrangement, forming departments or sectors of processes with fairly common nomenclature in factories, such as the stamping sector, machining department, painting section, inspection sector, etc. These settings do not identify the plant or its sectors the products manufactured, but by its processes (Krajewski \& Ritzman, 1999).

\subsubsection{Layout by product}

In this type of layout, the arrangement of jobs follows the sequence of the processing of the product, forming a set of equipment and keeping in common the sequential processing of parts of a product. In this, the processed resource is moved and the processing resource is static (Olivério, 1985).

\subsubsection{Cell layout}

According to Rother \& Harris (2002), a cell is defined as an arrangement of people, machines, materials and methods in which the process steps are close and occur in sequential order, through which the parts are processed in continuous flow. The processed components are grouped into families (similarity shapes and / or dimensions and / or processes). The physical layout of a cell "U" is the best known, but many different ways are possible.

\subsection{Takt time (TT)}

The German word 'takt' means to designate the measure of a musical composition, having been introduced in Japan in the 30s with the sense of 'production pace' when Japanese technicians were learning manufacturing techniques with German engineers (Shook, 1998). The Takt time (TT) is set from the market demand and the time available for production; it is the pace of production needed to meet demand. Mathematically, it results from the ratio of the time available for production (available capacity) and the number of units to be produced (demand).

\subsection{Kaizen}

According Werkema (2006), Kaizen is a Japanese term that means continuous improvement, being a methodology for achieving rapid improvements which consists in the organized use of common sense and creativity to enhance an individual process or an entire value stream.

According to Imai (1994), Kaizen philosophy means small improvements made in practice as a result of continuous efforts. Toyota has become a benchmark of the best practices and world-class concepts in the application of Kaizen, through the efficiency that conducts its processes, where these practices focus on eliminating any and all production loss, converting it into value (Rother, 2010). 


\section{Methodology}

\subsection{Dynamic simulation of factory signatures}

The following are the enabler concepts of the practice of teaching employed in the proposed methodology in the discipline of Plant Layout and Design, where its efficiency can be seen in practice after access to the necessary theoretical concepts can be seen in practice its efficiency.

In this section, aspects related to the proposal to create a simulated factory environment are described, which allowed 32 students to apply the concepts learned during the lectures on the content of types of layout and process improvement. Figure 2 shows the sequence of dynamics, which consists of the following steps:

They are also inserted in the dynamic: Client: Professor; Suppliers: Students; Product: Sheet with signatures of all the participants in the dynamic in Figure 3.

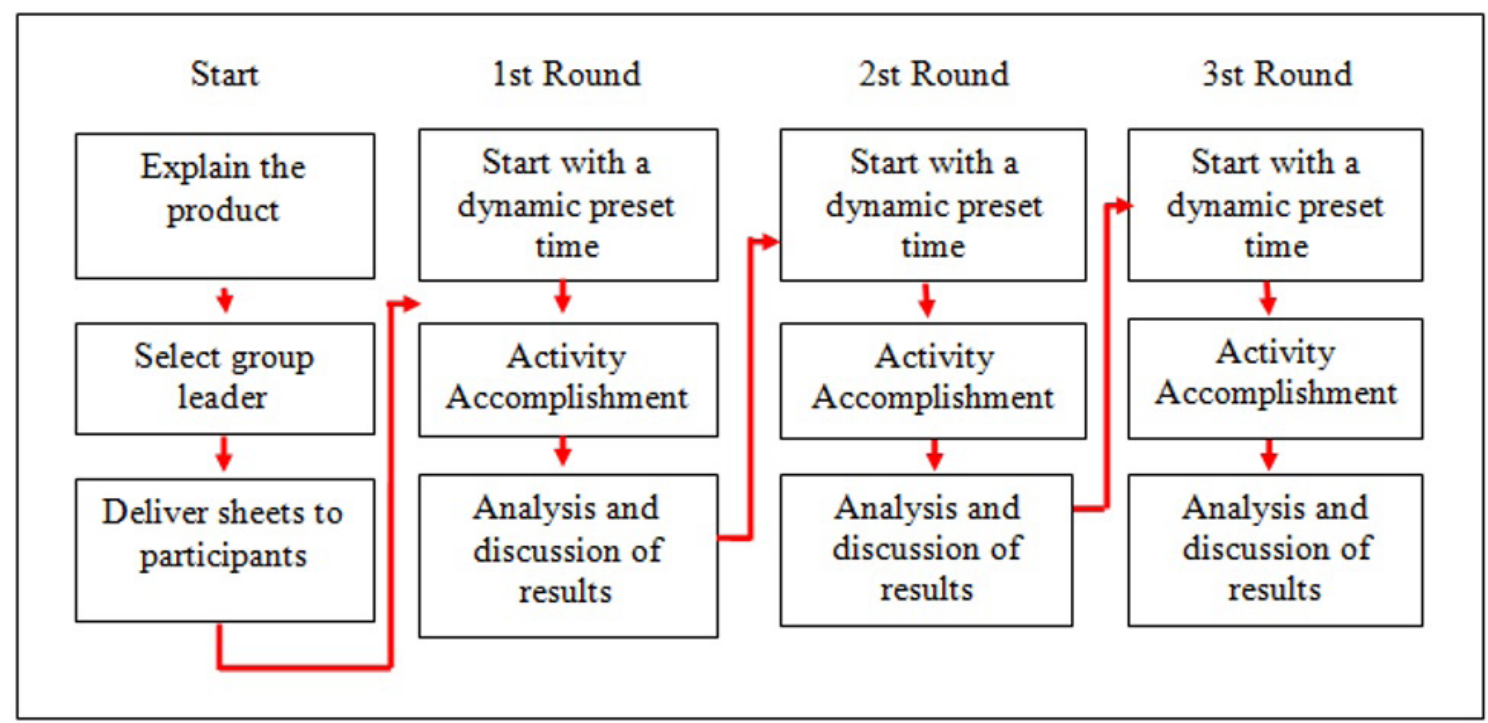

Figure 2. Sequence of dynamics. Source: Author.

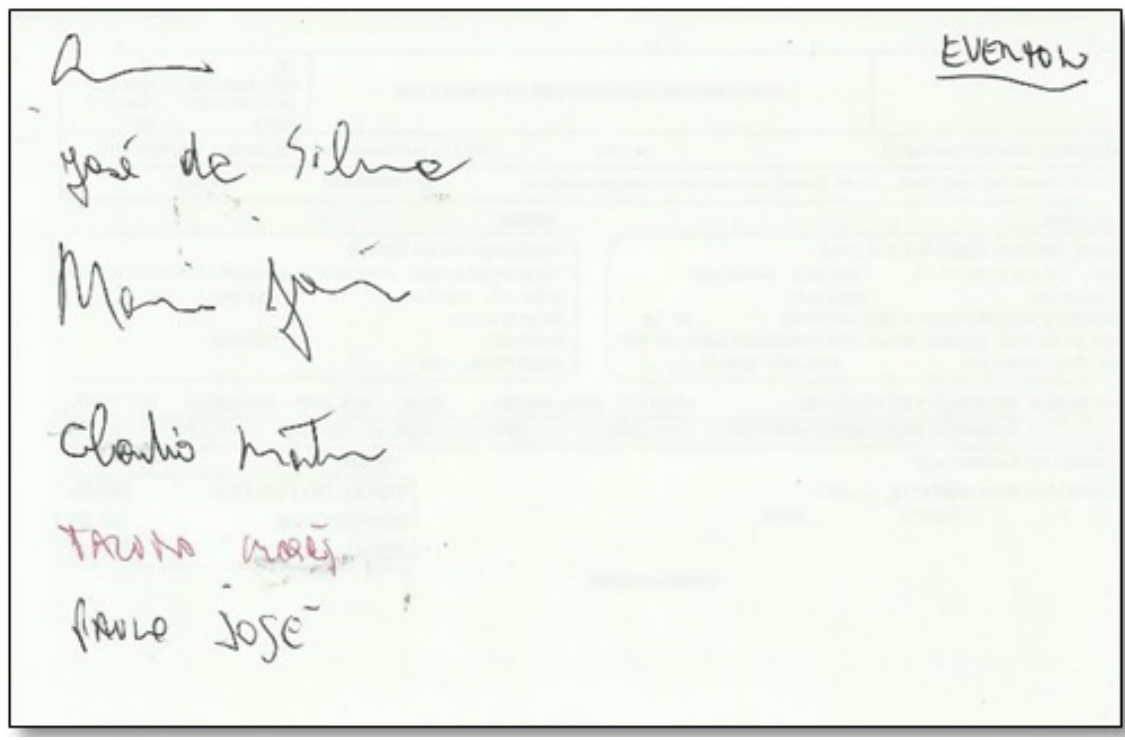

Figure 3. Example sheet of signatures. Source: Author. 


\subsection{Systematics of the dynamic}

- Each participant receives 01 blank sheet of paper, where they must fill in their name in the upper right corner to identify themselves;

- A leader is appointed by the students, who will be the production manager;

- Professor tells the time that will be available for the production rounds;

- Students organize the process for the production run;

- Time is recorded while students collect the signatures;

- After the time is reached the process is stopped with the professor's command;

- The sheets are checked to examine whether all signed within the stipulated time;

- Each sheet that does not contain the signatures of all participants is considered non-compliant and will be rejected by the client;

- Discussion of the results of the round and proposals for improvements.

\section{Results and discussion}

The proposal was developed and carried out with a group of a Production Engineering course in the Factory Layout and Design discipline, consisting of 32 students.

1st Round: Each participant is given a blank sheet of paper where they should fill in their name in the upper right corner to identify themselves. Initially a, time of 150 seconds was determined to conduct the first round of signature collection. With the time information for the activity and the demand, Takt time (TT) was calculated:

$T T=\frac{\text { Time available }}{\text { Demand }}$

$T T=\frac{150 \text { seconds }}{32 \text { sheets }}=4.7$ seconds $/$ sheet

After calculating and analyzing the Takt time (TT), it was discovered that each signature cannot exceed 4.7 seconds each; if exceeded it will not meet demand.

Using a timer, the Professor authorizes the start of the signature collection and triggers the 150-second time count. What can be seen at first glance it is that students begin the search for the signatures in a disorderly manner which generates a great disorder; in the first round the room layout was arranged as shown in Figure 4.

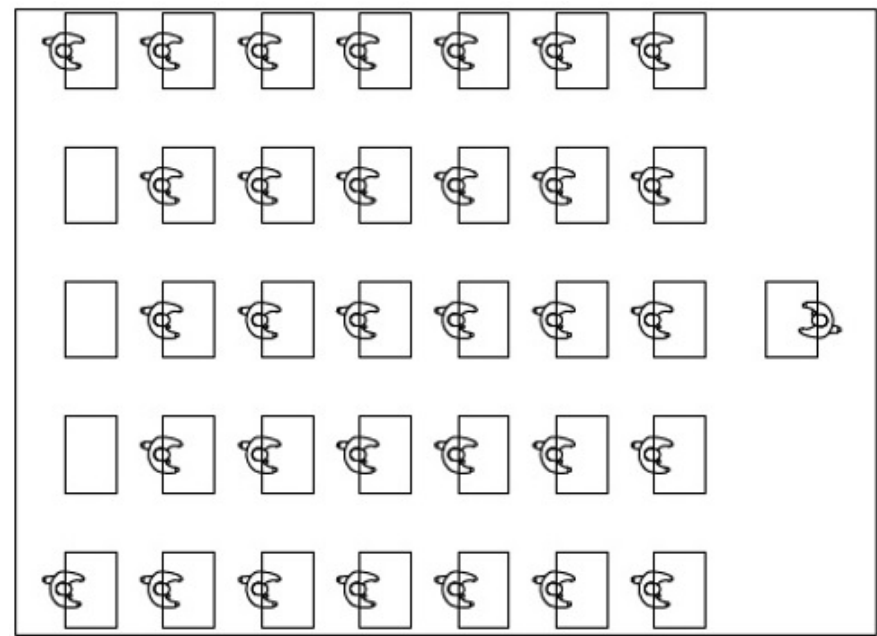

Figure 4. Classroom layout during the 1st round. Source: Author. 
As there was no prior organization for the realization of the 1st round, students were seeking signatures without an orderly method or flow, which generated great confusion and disorder because each one left his or her desk heading toward another to collect signatures.

The students completed the signatures on all sheets in 250 seconds. The customer (professor) said that the proposed time was extrapolated at 100 seconds. After the round, some time should be available for discussion and analysis of the round with the class to check the points where there were failures, and that did not favor the meeting of the demand.

Many reasons are raised by students during the debate, such as:

- Lack of leadership;

- Lack of time for organization;

- Organization Failure in the workspace;

- Little time for the collection of signatures;

- Lack of training.

After the discussion and survey of the causes, the professor provides a time of 5 minutes to the leader along with the group organizing the process for another round of production.

2nd Round: From the discussion, another round is suggested; however, with some changes from the previous one. The proposed time for completion of production will be 90 seconds. In this case Takt time (TT) will be:

$T T=\frac{\text { Time available }}{\text { Demand }}$

$T T=\frac{90 \text { seconds }}{32 \text { sheets }}=2.82$ seconds $/$ sheet

The calculated Takt time (TT) was 2.82 seconds for each sheet so that the demand can be met. The students analyzed the problems of the previous round and suggested a new layout for the process of signatures; the desks are arranged in line, according to Figure 5.

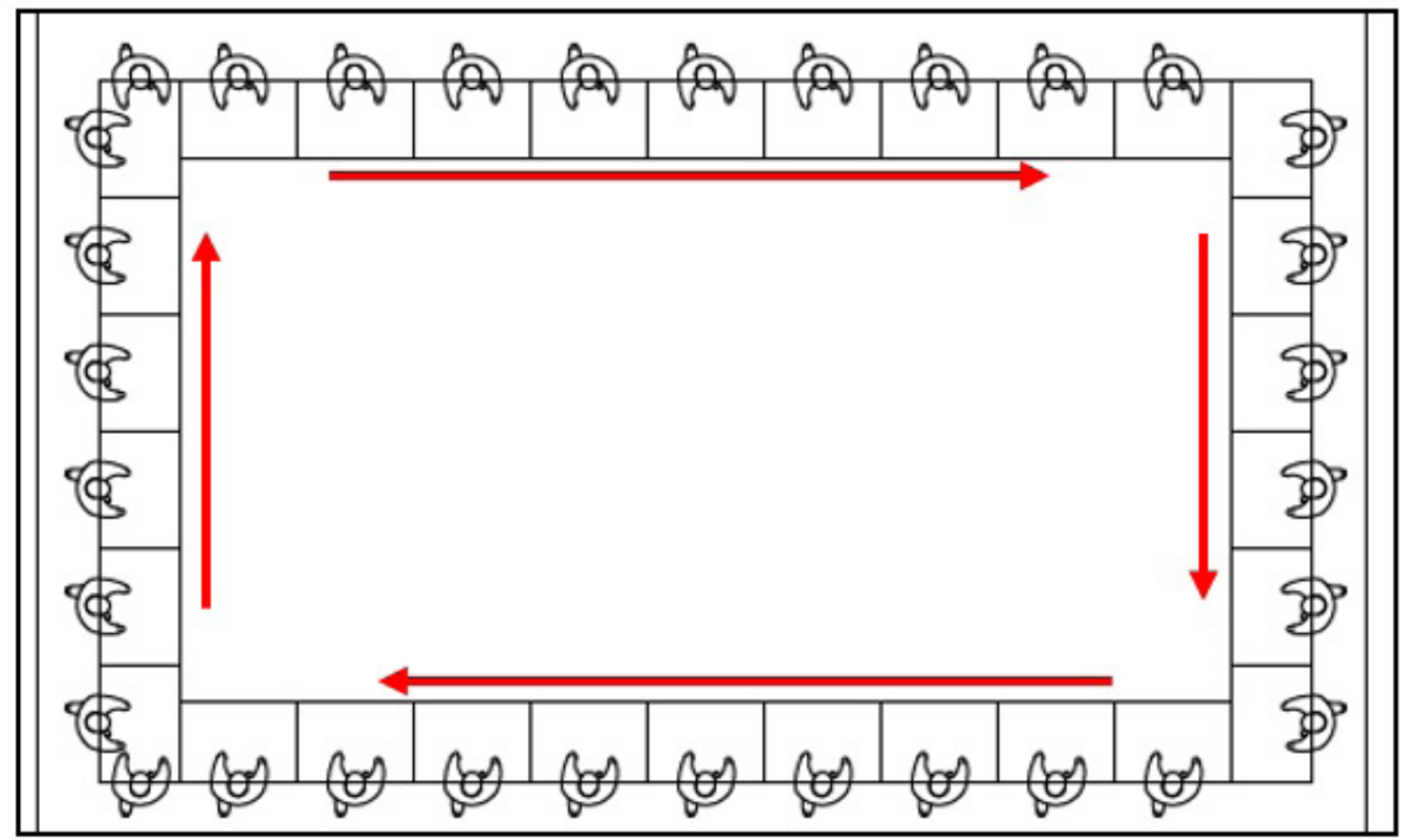

Figure 5. Classroom layout during the 2nd round. Source: Author. 
The students found that if the process is arranged in line, students are static (processing resource) and the sheets are in motion (processed resource), there will be the less unnecessary wasteful movement and transport, making the process more efficient.

After the new layout organization, the professor handed out new sheets on which each student put his or her name at the top right of the page, stating that the new round would start and everyone had to stay in their proper places. The timer is triggered and the sheets are passed among the students to perform the signature.

In the second round, the students complete the production of all the signatures in 75 seconds, before the stipulated time that was 90 seconds, which generates great satisfaction in the participants for having improved the process and reached the goal. It could be observed that in reaching the goal, some situations were identified, such as the presence of some production bottlenecks where some sheets were piling up; these bottlenecks were generated due to the size of the signature of some students. After the round, the professor checks and validates the sheets to examine whether all contain 32 signatures, and the production lot is approved.

3rd Round: Professor suggests another round of production to instigate students to reduce waste and eliminate bottlenecks that were seen in the previous round. A time of 5 minutes is available for the students to make a new debate to improve the process. The professor reports that the time for delivery of the lot shall be reduced to 60 seconds; the Takt time (TT) is recalculated:

$T T=\frac{\text { Time available }}{\text { Demand }}$

$T T=\frac{60 \text { seconds }}{32 \text { sheets }}=1.875$ seconds $/$ sheet

Students identified the problems of the previous round and suggested that each give only one look in the sheet and that the layout be changed to the positional type, where the processing resource (student) moves and the processed resource (sheet) is static; the students take a standing position and reduce the number of desks, having 02 students per desks to reduce movement during the course of signatures, as shown in Figure 6 .

After the new layout organization, the professor handed out new sheets, where each student put his or her name at the top right of the page, and reported that the new round would start, so everyone stays in their proper places. The timer is triggered and the students move toward the sheets to perform the signature.

In the third round, students complete the production of the signatures in 48 seconds, before the stipulated time that was 60 seconds, which generates great satisfaction in the participants for having improved the process and reached the goal.

But in reaching the objective, certain situations have been identified, such as the presence of some production bottlenecks where some students eventually bumped into each other when moving from desk to desk; these

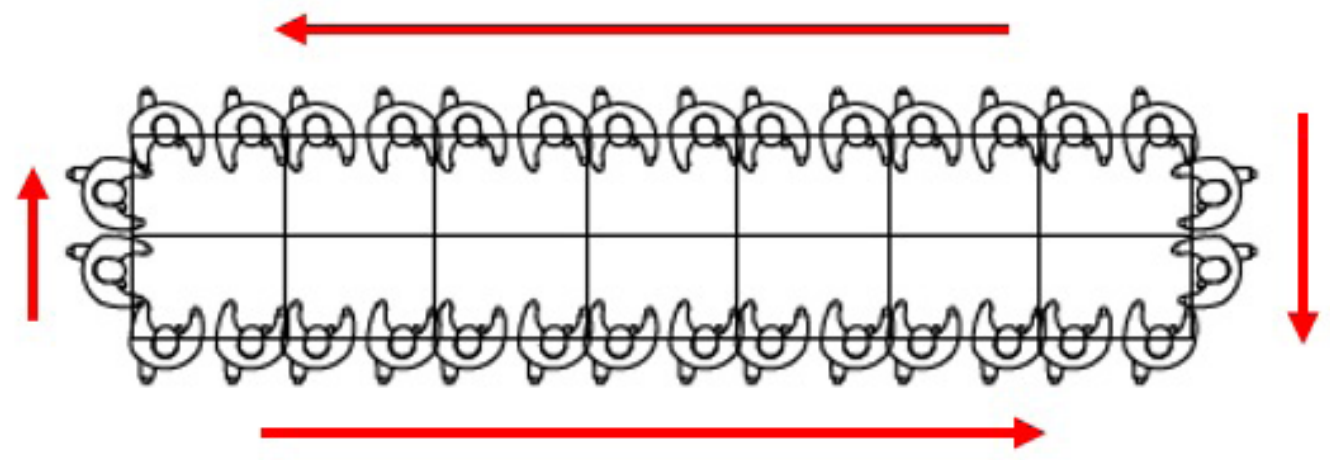

Figure 6. Classroom layout during the 3rd round. Source: Author. 
bottlenecks were generated due to the size of the signature of some students. After the round, the professor checks and validates the sheets to examine whether all contain 32 signatures, and the production lot is approved.

This dynamic shows that the continuous improvement process is constant, because if they had performed more rounds, the process would be improved in every situation, as waste is always noticed in every round.

\subsection{Closure of dynamics}

The closure of dynamics must highlight, in brief, the initial state of the process, to check whether the goals have been achieved and what has been improved after each round. Performing a comparison of the first to the third round, note that there was a reduction in execution time of the activity from the second round; this improvement in time was achieved due to the search for continuous improvement in the process layout, and the proposals for improvement performed after the initial round were evident, as in the last two rounds the production was performed before the proposed time, as shown in Figure 7.

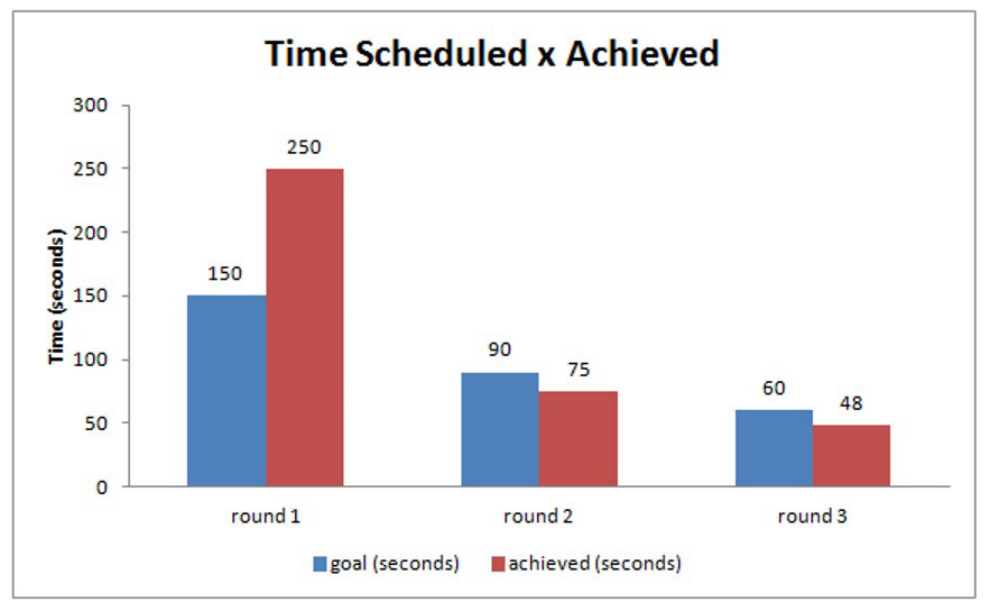

Figure 7. Chart time set $\times$ performed. Source: Author.

Note that in round 02 there was the fulfillment of production with a gap of 15 seconds and round 03 had a gap of 12 seconds, which shows that the layout organization, elimination of waste and the team commitment were crucial to achieving goals.

At the end, a period of time should be reserved for the participants so that they can envision new improvements that could still be effected in the process. Finally, the mediator of the dynamics should encourage participants to comment on the lessons learned and the contribution in shaping the activity provided.

\subsection{Evaluation of the dynamic}

After performing the analysis, a questionnaire was distributed in order to obtain student feedback in the activity performed. Anonymous questionnaires were composed of 04 questions:

- Learning: Did your participation in the dynamics facilitate your learning of theoretical concepts of discipline?

- Motivation and involvement: Did the application of the dynamics of learning make the class more interesting and motivate you to participate more in the discipline?

- Practice of Perception: Did the dynamics of learning allow you to identify the types of existing layouts in the processes more easily in real situations?

- Importance and continuity: Do you think it is fundamental that this dynamic is always used in the discipline of Plant Layout and Design?

The result of the questionnaire is shown in Table 1. 
Table 1 . Search results applied to the participants of the dynamic.

\begin{tabular}{|c|c|c|}
\hline \multirow{5}{*}{$\begin{array}{l}\text { 1. Learning: Did your participation in the dynamics facilitate your learning of } \\
\text { theoretical concepts of the discipline? }\end{array}$} & 1 totally agree & $46 \%$ \\
\hline & 1 agree & $54 \%$ \\
\hline & Neither agree nor disagree & $0 \%$ \\
\hline & Disagree & $0 \%$ \\
\hline & Strongly disagree & $0 \%$ \\
\hline \multirow{5}{*}{$\begin{array}{l}\text { 2. Motivation and involvement: Did the application of the dynamics of learning } \\
\text { make the class more interesting and motivate you to participate more in the } \\
\text { discipline? }\end{array}$} & 1 totally agree & $81 \%$ \\
\hline & 1 agree & $19 \%$ \\
\hline & Neither agree nor disagree & $0 \%$ \\
\hline & Disagree & $0 \%$ \\
\hline & Strongly disagree & $0 \%$ \\
\hline \multirow{5}{*}{$\begin{array}{l}\text { 3. Practice of Perception: Did the dynamics of learning allow you to identify } \\
\text { the types of existing layouts in the processes more easily in real situations? }\end{array}$} & 1 totally agree & $19 \%$ \\
\hline & 1 agree & $73 \%$ \\
\hline & Neither agree nor disagree & $4 \%$ \\
\hline & Disagree & $4 \%$ \\
\hline & Strongly disagree & $0 \%$ \\
\hline \multirow{5}{*}{$\begin{array}{l}\text { 4. Importance and continuity: Do you think it is fundamental that this dynamic } \\
\text { is always used in the discipline of Plant Layout and Design? }\end{array}$} & 1 totally agree & $85 \%$ \\
\hline & 1 agree & $15 \%$ \\
\hline & Neither agree nor disagree & $0 \%$ \\
\hline & Disagree & $0 \%$ \\
\hline & Strongly disagree & $0 \%$ \\
\hline
\end{tabular}

Source: Author.

As can be seen in Table 1, the activity was well accepted by the students. Qualitatively analyzing the effects of the application, the professor noticed a significant increase in the students' motivation after participating in the dynamics.

According to the classification of Snider \& Balakrishnan (2013), the activity presented falls as an active learning dynamic, semi-structured experiential way. In this case, students go through a process of experimentation with well-defined rules and perform a simple activity that can be inserted in the context of regular class.

\section{Conclusion}

This paper described a teaching dynamic used to understand the concepts of layout, continuous improvement, teamwork, process improvement and elimination of waste. The activity followed the philosophy of active learning, encouraging students to experience situations that help them to consolidate theoretical concepts and construct their own knowledge.

New teaching methods have increasingly been highlighted in the universities. However, using these methods has only occurred in a relatively timid manner, and therefore require a lot of resources, both financial and intellectual in some cases.

The application of the dynamic signature's factory with the undergraduate students of the Production Engineering Course proved to be very interesting. This dynamic has become an additional resource for teaching Production Engineering. The concepts about the types of layout, Kaizen, Takt time (TT), production balancing, and teamwork are easily transmitted to the students, and make a much more attractive class from the didactic point of view.

The experiential learning (through educational games) shifts the main role of the teaching-learning process to the student, who becomes the center of the process, unlike traditional teaching that focuses on the role of the professor. This facilitates greater involvement through the desire to search for competitive and cooperative learning. The group work prevails over the expository and individual presentation of the professor.

Some doubts always occur during the performance, especially when working with a large number of students; the professor must always strive as much as possible to maintain organization on site the day of activity.

As for the results, the change caused by the realization of the dynamic and breaking the routine of lectures stands out on part of the students. They emphasize that topics often worked on only theoretically can be experienced in practice, demonstrating possible cases and difficulties they will face in the manufacturing environment. The answers to the evaluation questionnaire, which was applied immediately after the completion of the dynamic, confirmed the widespread acceptance that it had among students. 
The creation of this game enabled the generation of a model that adequately approximated reality. The good results encourage further education, with possible consequences for other disciplines of the Production Engineering area, such as: Planning and Production Control (PPC); Quality Management, Industrial Organization, and Lean Production. It can also be applied in the Business Administration major in Production Management and Operations course.

\section{References}

Auster, E. R., \& Wylie, K. K. (2006). Creating active learning in the classroom: a systematic approach. Journal of Management Education, 30(2), 333-353. http://dx.doi.org/10.1177/1052562905283346.

Billington, P. J. (2004). A classroom exercise to illustrate lean manufacturing pull concepts. Decision Sciences Journal of Innovative Education, 2(1), 71-76. http://dx.doi.org/10.1111/j.0011-7315.2004.00021.x.

Bonwell, C. C., \& Eison, J. A. (1991). Active learning: creating excitement in the classroom (ASHE-ERIC Higher Education Report, 1), Washington: George Washington University.

Bordenave, J. E. D., \& Pereira, A. M. (1985). Estratégias de ensino-aprendizagem. Petrópolis: Vozes.

Carvalho, A. C. B. D., Porto, A. J. V., Belhot, R. V. (2001). Aprendizagem significativa no ensino de engenharia. Production, 11(1), 81-90.

Dillenbourg, P. (1999). What do you mean by collaborative learning? In P. Dillenbourg. Collaborative-learning: cognitive and computational approaches (pp. 1-19). Oxford: Elsevier.

Felder, R. M., \& Henriques, E. R. (1995). Learning and teaching styles in foreign and second language education. Foreign Language Annals, 28(1), 21-31. http://dx.doi.org/10.1111/j.1944-9720.1995.tb00767.x.

Gokhale, A. A. (1995). Collaborative learning enhances critical thinking. Journal of Technology Education, 7(1), 22-30. http://dx.doi. org/10.21061/jte.v7i1.a.2.

Heriot, K. C., Cook, R., Jones, R. C., \& Simpson, L. (2008). The use of student consulting projects as an active learning pedagogy: a case study in a Production/Operations Management course. Decision Sciences Journal of Innovative Education, 6(2), 463-481. http:// dx.doi.org/10.1111/j.1540-4609.2008.00186.x.

Imai, M. (1994). Kaizen: a estratégia para o sucesso competitivo. São Paulo: IMAM.

Krajewski, L. J., \& Ritzman, L. P. (1999). Operations management: strategy analysis (5th ed.). Reading: Addison-Wesley Longman.

Lambrecht, M., Creemers, S., Boute, R., \& Leus, R. (2012). Extending the production dice game. International Journal of Operations \& Production Management, 32(12), 1460-1472. http://dx.doi.org/10.1108/01443571211284197.

Miyashita, R., Oliveira, L. F. V. S. M., \& Yoshizaki, H. T. Y. (2003). Os jogos de empresas como instrumento de treinamento em logística empresarial. In Anais do $10^{\circ}$ Simpósio de Engenharia de Produção (pp. 1-10), Bauru.

Moreira, M. A., Caballero, M. C., \& Rodríguez, M. L. (1997). Aprendizagem significativa: um contexto subjacente. In Actas del Encuentro Internacional sobre el Aprendizaje Significativo (pp. 19-44). Burgos, España.

Moscinski, J. (2007). Changing tools and methods in engineering education. In Proceedings of the International Conference on Engineering Education (pp. 1-5), Coimbra, Portugal. Coimbra: 1CEE.

Mury, A. R. (2002). Simulando a cadeia de suprimento através de um jogo logístico: um processo de treinamento (Doctor thesis). Programa de Pós-graduação em Engenharia de Produção, UFRJ/COPPE, Rio de Janeiro.

Nigel, S., Chambers, S., \& Johnston, R. (1999). Administração da produção. São Paulo: Atlas.

Nunes, A. 1. B. L., \& Silveira, R. N. (2008). Psicologia da aprendizagem: processos, teorias e contextos. Fortaleza: Liber Livro.

Olivério, J. L. (1985). Projeto de fábrica: produtos, processos e instalações industriais. São Paulo: Instituto Brasileiro do Livro Científico.

Prince, M. (2004).Does active learning work? A review of the research. The Journal of Engineering Education, 93(3), 223-231. http:// dx.doi.org/10.1002/j.2168-9830.2004.tb00809.x.

Rother, M. T. (2010). Kata: gerenciando pessoas para melhoria, adaptabilidade e resultados excepcionais. Porto Alegre: Bookman.

Rother, M., \& Harris, R. (2002). Criando fluxo contínuo: um guia de ação para gerentes, engenheiros e associados da produção. São Paulo: Lean Institute Brasil.

Santos, L. C., Gohr, C. F., \& Vieira Junior, M. (2012). Simulation of assembly operations using interchangeable parts for OM education: a hands-on activity with water pipe fittings. International Journal of Operations \& Production Management, 32(12), 1427-1440. http://dx.doi.org/10.1108/01443571211284179.

Santos, L. C., Gohr, C. F., \& Vieira Junior, M. (2013). Robocano: uma dinâmica alternativa para ensinar e aprender gestão da produção. Revista Gestão Industrial, 9(1), 122-146.

Shook, Y. (1998). Bringing the Toyota Production System to the United States: a personal perspective. In J. Liker (Ed.), Becoming lean: inside stories of U.S. manufacturers. Portland: Productivity Press.

Silva, A. L. D., \& Rentes, A. F. (2012). Um modelo de projeto de layout para ambientes job shop com alta variedade de peças baseado nos conceitos da produção enxuta. Gestão \& Produção, 19(3), 531-541. http://dx.doi.org/10.1590/S0104-530X2012000300007.

Silva, W. M., \& Silva, E. C. L. (2006). Investigação dos dados sobre estilos de aprendizagem dos alunos freqüentadores da base de apoio ao aprendizado autônomo. Revista Científica da UFPA, 6(1), 1-8.

Smeds, R. (2003). Guest editorial: Simulation for accelerated learning and development in industrial management. Production Planning and Control, 14(2), 107-110. http://dx.doi.org/10.1080/0953728031000107707.

Snider, B. R., \& Eliasson, J. B. (2009). Push versus pull and mass customization: a LEGO inukshuk demonstration. Decision Sciences Journal of Innovative Education, 7(2), 411-416. http://dx.doi.org/10.1111/j.1540-4609.2009.00225.x.

Snider, B., \& Balakrishnan, J. (2013). Lessons learned from implementing web-based simulations to teach operations management concepts. INFORMS Transactions on Education, 13(3), 152-161. http://dx.doi.org/10.1287/ited.2013.0108. 
Werkema, M. C. C. (2006). Ferramentas estatísticas básicas para o gerenciamento de processos. Belo Horizonte: Werkema Editora.

Zepke, N., \& Leach, L. (2010). Improving student engagement: ten proposals for action. Active Learning in Higher Education, 11(3), 167-177. http://dx.doi.org/10.1177/1469787410379680.

Received: Sept. 12, 2016

Accepted: Mar. 14, 2017 